\title{
Discussing the potential of the institutional theory to leverage service-dominant logic advancements
}

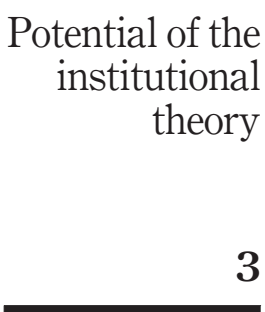

Received 7 January 2021 Revised 17 March 2021 Accepted 12 April 2021

\section{Advance/CSG, ISEG Lisbon School of Economics and Management,} Universidade de Lisboa, Lisbon, Portugal, and

Rui Vinhas Silva

ISCTE-Instituto Universitario de Lisboa, Lisboa, Portugal

\begin{abstract}
Purpose - Institutions play a central role in service-dominant logic. However, the discussion regarding how institutional theory supports service-dominant logic advancements is still insufficient. This paper aims to contribute to a discussion on the multiple service-dominant logic approaches to institutions.

Design/methodology/approach - This conceptual paper presents the characterization of the existing streams in the broad institutional literature, highlighting the differences among those streams and elaborates on how one of the discussed streams - neo-institutionalism - is suitable to support service-dominant researchers in understanding the role of institutions in markets and value co-creation.

Findings - The paper shows that the three institutional perspectives presented are used indistinctly by service-dominant logic and a greater fit between the service-dominant logic and the neo-institutionalism stands out.

Originality/value - The paper proposes that service-dominant researchers should look at the neoinstitutional stream as a particularly fertile ground for furthering their research.
\end{abstract}

Keywords Institutional theory, Institutions, Institutional logics, Neo-institutionalism,

Service-dominant logic, Rational choice institutionalism

Paper type Conceptual paper

\section{Introduction}

Service-dominant logic is a vibrant marketing perspective which provides a distinct lens to tackle value creation. It addresses service as a process, rather than as an outcome (Quader \& Sohel, 2018).

Recently, we have been witnessing the closing of the gap between institutional theory and marketing studies (Gonçalves, da Silva, \& Teixeira, 2019; Slimane, Chaney, Humphreys, \& Leca, 2019). Specifically, in service-dominant logic, institutions have been assuming a

(C) Sara Martins Gonçalves and Rui Vinhas Silva. Published in European Journal of Management Studies. Published by Emerald Publishing Limited. This article is published under the Creative Commons Attribution (CC BY 4.0) licence. Anyone may reproduce, distribute, translate and create derivative works of this article (for both commercial and non-commercial purposes), subject to full attribution to the original publication and authors. The full terms of this licence maybe seen at http:// creativecommons.org/licences/by/4.0/legalcode

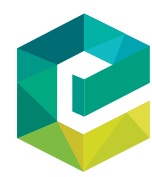

European Journal of Management Studies

Vol. 26 No. 1, 2021

pp. 3-16 2183-4172 DOI 10.1108/EJMS-01-2021-0004 
EJMS

26,1

prominent role and a combination of the two theories was suggested to further advance the "understanding of markets and marketing" (Vargo \& Lusch, 2016, p. 20. Vargo \& Lusch, 2018).

In turn, there is a well-established and wide body of literature on institutional theory, which encompasses different approaches of the interplay between institutions and society. These differences in perspective gave rise to three streams of institutional research, namely, rational-choice institutionalism, old institutionalism and neo-institutionalism. Each stream has a distinctive view on institutions with different assumptions regarding human nature and human action and different objects of study that make the resulting studies hardly compatible.

Apart from a few exceptions (Vargo \& Lusch, 2016), discussion regarding how institutional theory can support service-dominant logic advancements is still scarce. In particular, it is necessary to look at each institutional stream to understand its particular approach to institutions.

Against this background, the purpose of this paper is not to present a comprehensive literature review, but rather to contribute to a discussion on the multiple existing approaches to institutions in two ways. First, we present the characterization of the existing streams in the broad institutional literature, highlighting the differences among these streams, and second, we elaborate on how one of the discussed streams - neoinstitutionalism - is suitable to support service-dominant researchers in understanding the role of institutions in markets and value co-creation.

The paper is structured as follows. Section 2 addresses the service-dominant logic evolution, especially the role of institutions in the literature on service. Section 3 provides a characterization of the institutional theory. It begins with an overview of all the streams of research and then progresses by specifically concentrating on the neo-institutional stream of research. In Section 4, the importance of addressing the distinctive features of the institutional streams of research is discussed and the fit between the service-dominant logic and neo-institutional theory. Finally, Section 5 summarizes the main conclusions, the contributions and the limitations of this work.

\section{Institutions in service research}

In 2004, Vargo and Lusch introduced the conceptual basis for service-dominant logic (Vargo \& Lusch, 2004). Specifically, it argues that the use of competencies constitutes "service," regardless of its material or immaterial form (Vargo \& Lusch, 2004). Service-dominant logic arises as a theoretical framework that offers a perspective of value creation between a firm and its customer through a service exchange (Vargo \& Lusch, 2004).

When examined through the service-dominant logic lens, value is mutually created (i.e. co-created) during a process that unfolds and emerges over time through service exchange among the parties involved in that exchange (Akaka \& Vargo, 2014; Frow \& Payne, 2011; Lusch \& Webster, 2011). Value co-creation is thus understood as being the set of "actions of multiple actors, who are often unaware of each other, that contribute to each other's wellbeing" (Vargo \& Lusch, 2016, p. 8).

In its initial formulation, service-dominant logic started by dealing with the dyadic processes of exchange between a firm and its customer (Vargo \& Lusch, 2004). However, recently a systemic perspective where the co-creation of value occurs within service ecosystems was adopted (Ballantyne \& Varey, 2008; Gummesson \& Mele, 2010). A service ecosystem or a "system of service systems," has the potential to represent the interrelationships among different types of actors and along with different levels of context in a single framework (Chandler \& Vargo, 2011; Vargo \& Akaka, 2009). This framework is 
defined as "a configuration of people, technologies and other resources that interact with other service systems to create mutual value" (Vargo \& Lusch, 2016, p. 11). Specifically, service-dominant logic sees service ecosystems as a context comprising three levels: microlevel, meso-level and macro-level. Above each of these three levels, there is a meta-layer. This evolution results from the influence of theories such as consumer culture theory (Arnould \& Thompson, 2005; Merz, He, \& Vargo, 2009; Payne, Storbacka, \& Frow, 2008) or network and system theories (Barile \& Polese, 2010a, 2010b) on service-dominant logic (McColl-Keneddy \& Cheung, 2019; Vargo \& Lusch, 2016).

This feature of service-dominant logic - ecosystem - is of utmost importance for value creation for three different reasons. First, an actor's context influences his access to resources, and hence, it also influences resource integration. That is to say that each ecosystem conditions the use and the value of resources. Second, the context in which an actor is embedded can facilitate or hinder his activity. This is based on Granovetter's theory of structural embeddedness (Granovetter, 1985), according to which individuals and organizations are embedded in a context, which, in turn, influences the individual's action. Service-dominant logic, therefore, sees context as a resource for that actor. Third, context frames exchange and consequently, value creation from the idiosyncratic perspective of each actor involved in service provision (Chandler \& Vargo, 2011).

Service-dominant logic researchers have gradually been giving emphasis to the systemic nature of interactions between actors within an ecosystem (Akaka, Vargo, \& Lusch, 2013; Edvardsson, Tronvoll, \& Gruber, 2011), which highlights the importance of institutions.

Institutions play an important role in service ecosystems, as they influence human actions and interactions (Akaka et al., 2013) and accordingly value co-creation, as well as economic and social performance (Edvardsson, Kleinaltenkamp, Tronvoll, Mchugh, \& Windahl, 2014). Vargo and Lusch (2016) are more specific and argue that the importance of institutions is because of human limited cognitive abilities which are connected with the use of institutions. Akaka, Vargo, and Schau (2015) stress the influence that institutions have on value which is rooted in individual experience.

Furthermore, institutions play a central role in innovation through institutionalization (i.e. the maintenance, disruption and change of institutions) (Vargo, Wieland, \& Akaka, 2015).

Finally, institutions are capable of synchronizing actors in mutual resource integration, either in an enabling or in a constraining way. Institutions accordingly also influence the efficiency that lies in the service ecosystem and conversely, service ecosystems also shape, change and recreate institutions (Edvardsson et al., 2014).

Despite the importance assigned to institutions in interactions occurring in service ecosystems, a discussion on the multiple approaches to institutions and their compatibility with service-dominant logic premises has not yet been held, despite a few exceptions (Vargo \& Lusch, 2016) As a result, service-dominant researchers have been supporting their works on multiple institutional perspectives, interchangeably, which result in different understandings of what institutions are. In some cases, we find the simultaneous use of two perspectives in the same paper. In this context, service-dominant logic addressing institutions would benefit from an institutional literature review.

\section{Institutions in institutional theory}

To contribute to the discussion on how the existing institutional literature can support service researchers, the following subsection presents the characterization of the existing streams in the broad institutional literature that highlight the differences among these streams. Furthermore, Subsection 2 looks closer at one of the institutional streams of
Potential of the institutional theory 
EJMS

26,1

research presented - Neo-institutionalism - to address the fit between the latter and servicedominant logic.

\section{Institutional theory and its multiple perspectives}

Institutional theory is a wide body of thought that is formed by different perspectives regarding the interplay between institutions and society. These differences in perspective gave rise to three streams of institutional research and each stream has a particular definition of institutions as a consequence of the approach and the assumptions considered (Scott, 2013).

The first stream of research is typically addressed in Economics (Moe, 1984; North, 1990) and assumes that individuals make their choices in a rational way to maximize their interests. This stream of institutional research, which is also known as rational choice institutionalism, devotes special attention to how behavior is influenced by explicit regulatory processes involving rule-setting, monitoring, compliance and implementing sanctions (i.e. rewards or punishments). Within this stream, institutions are the "humanly devised" rules of society (North, 1990) that structure human interactions by providing plausible expectations about how other individuals are likely to behave (Hall \& Taylor, 1996). The logic of institutions in this stream is therefore instrumental, as laws and rules are set to achieve interests (Geels, 2004; Scott, 2013).

The second stream of research or the 'old institutionalism, considers institutions to be "the formal or informal procedures, routines, norms and conventions embedded in the organizational structures” (Hall \& Taylor, 1996, p. 6). This stream, which is heavily supported in Sociology, assumes that individual rationality is driven by a "logic of appropriateness" (March, 1991), under which choice is oriented by a moral framework that defines the legitimate goals and the means to achieve them and also the obligations to others (Geels, 2004; Scott, 2013). For this research stream, moral aspects are of utmost importance, as they are the basis of a stable social order (Scott, 2013).

The third stream of research, which is often known as neo-institutionalism, emerged within the field of organization studies. It proposes that an actor does not adopt a behavior because it is more efficient or appropriate, but rather because it is seen to be the legitimate behavior within the actor's social context (Greenwood, Oliver, Sahlin, \& Suddaby, 2008; Wooten \& Hoffman, 2008). Furthermore, it is argued that many practices should be seen as part of cultures (i.e. a common framework of meanings), which, in turn, assume a central place in this stream (Scott, 2013).

Within this perspective, institutions are "more-or-less taken-for-granted repetitive social behavior that is underpinned by normative systems and cognitive understandings that give meaning to social exchange, and thus, enable self-reproducing social order" (Greenwood et al., 2008, pp. 4-5). In this setting, action results from both rational calculations and nonrational premises held by the individual. These non-rational premises are socially constructed models, assumptions and schemas that enter into a routine and become takenfor-granted. (Scott, 2013).

Conversely, Scott $(1987,2008,2013)$ proposes that these three streams of research could be approached as three dimensions of the institutions' concept, namely, the regulative, the normative and the cultural-cognitive dimensions that, "together with associated activities and resources, provide stability and meaning to social life" (Scott, 2013, p. 56). Nevertheless, as Scott (2013) acknowledges, although it is possible to conceptualize institutions as a combination of regulative, normative and cultural-cognitive elements (Mizruchi \& Fein, 1999), each pillar is studied by a different stream of institutional research and follows different assumptions. As Phillips and Malhotra (2008) point out, contrary to the cultural-cognitive 
mechanisms, the coercive and normative mechanisms are externally managed by different actors. Furthermore, coercive and normative mechanisms result in strategic action, while cultural-cognitive mechanisms work through shaping cognition. It is these reasons, according to Phillips and Malhotra (2008) that make these three mechanisms irreconcilable.

\section{Neo-institutional approach to institutions}

Neo-institutionalism emerged in the late 1970s, supported by the works of Meyer and Rowan (1977), Zucker (1977) and DiMaggio and Powell (1983), which are considered by many researchers to be the foundational papers of this research stream (DiMaggio \& Powell, 1991; Greenwood et al., 2008; Scott, 2013). The differences between this and the other two approaches to institutions that have already been described (i.e. rational choice institutionalism and old institutionalism) led Powell and DiMaggio (1991) to claim a "new institutionalism" in organization theory, according to the argument that this new institutional approach differs in a number of ways from the others. This paper identifies three distinguishing features of neo-institutionalism, namely, the institutional context, the concept of institutional logics and the agency/structure debate. These features and their implications are now detailed.

The institutional context. In a foundational paper, DiMaggio and Powell (1983) proposed that organizations are not always motivated by efficiency. Rather, organizations' behaviors are driven by legitimacy concerns in the eyes of their stakeholders, as legitimate behavior increases the likelihood of organizational success. The appearance of rational behavior is expected of organizations, and thus, each organization behaves according to those "widespread social understandings that define what it means to be rational" (i.e. institutional context) in its particular relational network (Greenwood et al., 2008, p. 3). This view has three main implications that need to be considered, as some of them are still underexplored in marketing literature.

First, organizations are influenced by their institutional context. This institutional context is a higher-order concept that represents the rules, norms and ideologies of the wider society and it is disseminated through the relational networks (Meyer \& Rowan, 1983; Wooten \& Hoffman, 2008). Each relational network adopts as legitimate an idiosyncratic group of rules, norms and ideologies and the more complex the relational network is, the more likely that institutional context turns into formal rules (DiMaggio \& Powell, 1983). The primary focus of neo-institutionalists is the relationship between organizations and the institutional context, with most researchers being devoted to understanding how institutional contexts influence organizations, especially during the early stages of neoinstitutionalism. To identify and describe an institutional context, researchers make use of a unit of analysis that comprises "the community of organizations that partakes of a common meaning system and whose participants interact more frequently and fatefully with one another than with actor outside de field" (Scott, 1995, p. 56) - which they named the "organizational field." An organizational field can comprise actors such as "the government, critical exchange partners, sources of funding, professional and trade associations, special interest groups and the general public" (Wooten \& Hoffman, 2008, p. 131).

Second, the central role of cognition in neo-institutional research. As pointed out above, neo-institutionalists moved away from the assumption of economic rationality and assumed that individuals are "boundedly" rational, as cognitive processes have several limitations such as the incomplete knowledge of their environment, limited "computational capabilities" and limited time (Guercini, La Rocca, Runfola, \& Snehota, 2014). Furthermore, neoinstitutionalists consider that behavior results from both rational calculations and individuals' non-rational premises. These non-rational premises are schemas (i.e. patterns of
Potential of the institutional theory 
EJMS

26,1

thought or action that organize categories of information and the relationships among them) that enter into a routine and become taken-for-granted. The cognitive schemas facilitate individual's assessments and decisions and are prescribed by the institutional context (DiMaggio, 1997; Scott, 1987; Thornton, Ocasio, \& Lounsbury, 2012)

Third, the institutional context is a broad cultural framework. Culture is a central concept in neo-institutional studies, as this research stream assumes that the actors' internal interpretative processes are shaped by external cultural frameworks (Scott, 2013). This conception of culture differs significantly from the one accepted in the old institutionalism. The former is defined as a "tool kit of symbols, stories, rituals and world-views, which people may use in varying configurations to solve different kinds of problems" (Swidler, 1986, p. 273), while the latter is monolithic and internally coherent across groups and situations (DiMaggio, 1997; Scott, 2013).

DiMaggio (1997) argues that culture works through the interaction among information, mental structures and symbolic systems. The information is distributed across actors in a patterned, but not in a highly differentiated way. In turn, mental structures shape the way actors attend to, interpret, remember and respond emotionally to the information owned and symbolic systems are external to actors and can include the content of the talk, elements of the constructed environment, media messages and meanings embedded in observable activity patterns. While actors have several mental structures available to them to make decisions, the decision regarding which one to use is guided by "cultural cues" which are available in the cultural framework in which the actor is embedded.

Cultural frameworks operate at multiple levels and these levels are not sealed, but rather embedded in each other (Scott, 2013). Organizations and individual actors are seen as embedded in industries, professional groups or national societies and the contexts "penetrate the organization, creating the lenses through which actors view the world and the very categories of structure, action and thought" (DiMaggio \& Powell, 1991, p. 13). How neoinstitutionalists consider these cultural frameworks have been identified as the second distinguishing feature of neo-institutionalism.

Institutional logics. The most widespread and broadly accepted cultural framework was proposed by Friedland and Alford (1991). According to these authors, a cultural framework, "interinstitutional cultural system" in the authors' words, is formed by a group of multiple, independent and often contradictory institutional logics. Institutional logics assume prominence over the concept of institutions in neo-institutional literature.

Institutional logics are "a set of material practices and symbolic constructions" that constitute an institutional order's "organizing principles" and are "available to organizations and individuals to elaborate." These logics are "symbolically grounded, organizationally structured, politically defined and technically and materially constrained." (Friedland \& Alford, 1991, p. 248). Each logic prescribes a frame of reference that shapes the actor's actions and the actor's sense of self (Thornton et al., 2012).

Furthermore, Friedland and Alford (1991) propose that western societies have a common cultural framework comprising the logics of "capitalist market, bureaucratic state, democracy, nuclear family and the Christian religion." They provide the corresponding explanation:

"The institutional logic of capitalism is accumulation and the commodification of human activity. That of the state is rationalization and the regulation of human activity by legal and bureaucratic hierarchies. That of democracy is participation and the extension of popular control over human activity. That of the family is community and the motivation of human activity by unconditional loyalty to its members and their reproductive needs. That of religion, or science for that matter, is truth, whether mundane or transcendental, and the symbolic construction of reality within which all human activity takes place" (Friedland \& Alford, 1991, p. 248). 
Most recently, Thornton et al. (2012) proposed an updated interinstitutional cultural system. The former institutional logics remained in the model (i.e. the market, the state, the family and the religion logics) and three new logics were added: the profession, the corporation and the community logics.

The professional logic is summarized by Thornton et al. (2012) as being "under the influence of the professions it [sensemaking] does not, or does so in a tempered way, for example through concerns over personal reputation, professional association, and quality of craft." (p. 3), while "the corporation is a legal institution that has given rise to a wide range of economic activity because of its distinct advantages such as capital assimilation, ability to engage in contracts and limited liability for shareholders" (Thornton et al., 2012, p. 67). Finally, the community logic represents "a territory and the social action that is not restricted exclusively to the satisfaction of common economic needs of the communal economy" (Thornton et al., 2012, p. 68).

According to Thornton et al. (2012), each institutional logic represents a governance system that provides a frame of reference that precondition actors' sensemaking choices and this frame of reference shapes not only individual and organizational preferences and interests but also the group of behaviors by which interests and preferences are achieved within the area of influence of a specific institutional logic.

The institutional logics ideal-type framework proposed by Friedland and Alford (1991) and later by Thornton et al. (2012) has been used by a wide range of neo-institutionalists in several empirical settings (Almandoz, 2012; Battilana \& Dorado, 2010; Ferreira, Caruana, \& Cohen, 2015; Haveman \& Rao, 1997; Rao, Monin, \& Durand, 2003; Thornton \& Ocasio, 1999; Tilcsik, 2010; Townley, 1997).

The agency/structure debate. The institutional context consists of simultaneous, multiple logics and how actors deal with different, and sometimes even contradictory prescriptions from those logics is one of the central questions raised by neoinstitutionalism. Also known as the debate between agency and structure, it is this central question that meets the lesser agreement among researchers. The differences in the assumptions concerning the relationships among actors, organizations or individuals and their contexts are behind the lack of consensus.

On the one hand, to some researchers, actors have a limited degree of intentionality (i.e. agency), and therefore, tend to comply with institutional pressures (i.e. social structure). This perspective was particularly present in early neo-institutional studies, according to which organizations' primary concern is to conform to their organizational field's logics (i.e. isomorphism) to gain legitimacy (Meyer \& Rowan, 1977).

On the other hand, in the eyes of other researchers, actors possess autonomy, free-will and creativity that enables them to depart from institutional pressures or even make use of social structures to their own advantage (Hallett \& Ventresca, 2006; Hallett, 2010).

This everlasting debate between structure and agency has been evolving in neoinstitutional literature. While in the foundational work, the importance of structure in shaping human action was far superior to the individual agency (DiMaggio \& Powell, 1983; Meyer \& Rowan, 1977; Zucker, 1977), a new line of reasoning seems to be emerging in recent papers, where individuals are seen to be largely intentional and capable of using social structures to their own advantage (Binder, 2007; Delbridge \& Edwards, 2013; Ferreira et al., 2015; Hallett \& Ventresca, 2006; Hallett, 2010).

\section{Discussion}

Service-dominant logic is a marketing perspective that acknowledges the substantial contribution of institutional theory in providing a better understanding of the marketing
Potential of the institutional theory 
EJMS

26,1

phenomena. As a result, several service-dominant researchers have been conciliating the institutional theory and the service-dominant logic. Surprisingly, the discussion about how institutional theory can support service-dominant logic advancements is still insufficient, as institutions in service-dominant logic are approached through rational choice, the new institutionalism or even the integrated perspective proposed by Scott (1995, 2013), indistinctly. Furthermore, in some cases, different understandings of institutions can be found in a single paper that is presented as being similar. Examples are provided in Table 1.

As demonstrated, an institutional theory is not a unified body of literature. Rather, it is a heterogeneous theory composed of three distinct streams of research, as widely recognized among institutional researchers. The differences between the research streams are because of both different assumptions regarding human nature and human action and also to differences between objects of study that make the resulting theories hardly compatible.

The work of Scott $(1995,2013)$ became known for trying to conciliate these three perspectives of institutions. However, even the author acknowledges the difficulty of conceptualizing institutions as a combination of regulative, normative and culturalcognitive elements (Scott, 2013). In addition, Phillips and Malhotra (2008) put forward some explanations for this incompatibility, such as:

- coercive and normative mechanisms are externally managed by different actors, contrary to cultural-cognitive mechanisms; and

- coercive and normative mechanisms result in strategic action, while culturalcognitive mechanisms work through shaping cognition.

From the examples provided in Table 1, which follow a chronological sequence, we were unable to identify a trend in the use of institution's definition and it seems that the indiscriminate use of the different approaches to institutions persists over time. This is not a vulnerability by itself, for, as shown, the regulative, normative and cultural-cognitive perspectives on institutions are grounded in different assumptions, some of which are more compatible than others, with the premises that support service-dominant logic. Accordingly, we next address the fit between service-dominant logic and one of the perspectives - neoinstitutionalism.

Vargo and Lusch (2016) assert that "in spite of the traditional assumption of neoclassical economics that economic participants are highly calculative, rational actors, the evidence points toward very restricted cognitive abilities and "bounded rationality" (Simon, 1996). This implies the need for "cognitive shortcuts" (p. 17). When compared with the foundational premises of the three institutional streams of research detailed, this view of human rationality is particularly compatible with that of neoinstitutionalism.

Furthermore, recent service-dominant logic literature has gradually been building on some social construction premises, such as Berger and Luckmann (1967) proposition that all actors and their actions are social constructions (Edvardsson et al., 2011) and Granovetter's (1985) theory of structural embeddedness, to represent service exchange and value co-creation, such as those embedded in social ecosystems (Vargo \& Lusch, 2016) - which are the foundational principles of neo-institutionalism, as detailed above.

Finally, ecosystems - which are a central feature in service-dominant logic - are open, complex, multi-level and porous social systems (Chandler \& Vargo, 2011; Vargo \& Akaka, 


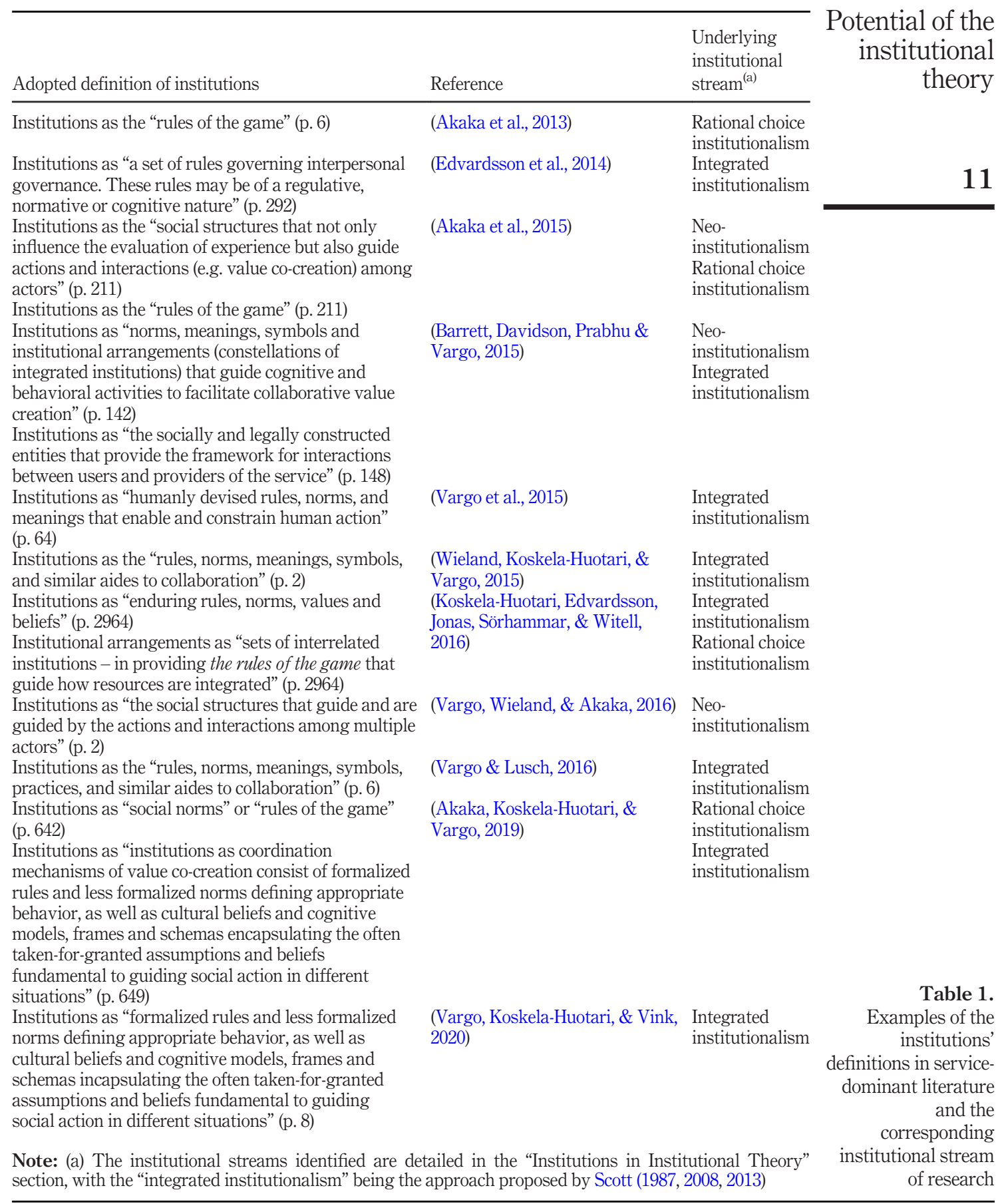


EJMS

26,1

2009; Vargo \& Lusch, 2016, 2018). Similarly, these social contexts' characteristics are also addressed by neo-institutionalists (Scott, 2013).

Against this background, this paper argues that neo-institutionalism is particularly suitable to support service-dominant logic advancements with regard to institutions.

However, the fit between these two theories is not perfect, as some differences also exist. One of these differences is the unit of analysis that is considered by the researchers. Typically dyads, triads or even complex networks as units of analysis are adopted as units in service-dominant logic, which explains the mutual interest in studying individual actors who, in effect, are the basis of the dyads, triads and complex networks (Chandler \& Vargo, 2011). In turn, neo-institutionalism adopts the organizational field as the main unit of analysis.

\section{Conclusion, contributions and opportunities for future research}

Institutions became a prominent concept in service-dominant logic, which led to service researchers' increasing interest in institutional theory. Institutional theory is a wide body of literature that encompasses different perspectives regarding institutions. These differences in perspective gave rise to three streams of institutional research, namely, rational-choice institutionalism, old institutionalism and neo-institutionalism. Scott $(1987,2008,2013)$ proposes an integrative approach to institutions that conciliates the three above-mentioned institutional streams. Based on examples collected from the service-dominant literature, this paper shows that the three perspectives are used indistinctly, without considering their differences. Additionally, it also offers a comparative analysis of the central concept according to the three institutional perspectives and stresses the main differences between these perspectives with the aim of encouraging deeper discussion among service-dominant researchers regarding how institutional approaches can support service-dominant logic.

After detailing the streams of service-dominant logic on the one hand and the three institutional theory streams, on the other hand, the greater fit between the service-dominant logic and the neo-institutionalism stood out. To support service-dominant researchers in their understanding of the role of institutions in markets and value co-creation according to the neo-institutional lens, the paper also comprehensively reviews neo-institutional literature.

This paper contributes to service-dominant literature by showing the distinctive epistemological characteristics of each institutional stream of research that should be considered by service researchers when they choose to adopt one institutional lens rather than the others.

The paper suggests that future service-dominant research should consider the neoinstitutional literature as a particularly fertile ground for furthering knowledge regarding service-dominant logic approaches to institutions. Specifically, we find that the institutional logic framework is particularly suitable for supporting the extension of service-dominant logic to service co-creation in ecosystems that have different and characteristics that have not yet been studied - such as non-profit ecosystems.

Finally, a possible limitation of this paper is that the arguments presented are based on the assumption that the higher the compatibility between the foundational premises of the two theories, the greater the fit between them, which may not necessarily always be the case. 


\section{References}

Akaka, M. A., Koskela-Huotari, K., \& Vargo, S. L. (2019). Further advancing service science with service-dominant logic: Service ecosystems, institutions, and their implications for innovation. Maglio, Kieliszewski, Spohrer, Lyons, Patrício and Sawatani (Eds.), Handbook of service science, 2, 641-659. Cham, Switzerland: Springer.

Akaka, M. A. \& Vargo, S. L. (2014). Technology as an operant resource in service (eco)systems. Information Systems and E-Business Management, 12(3), 367-384.

Akaka, M. A., Vargo, S. L., \& Lusch, R. F. (2013). The complexity of context: A service ecosystems approach for international marketing. Journal of International Marketing, 21(4), 1-20.

Akaka, M. A., Vargo, S. L., \& Schau, H. J. (2015). The context of experience. Journal of Service Management, 26(2), 206-223.

Almandoz, J. (2012). Arriving at the starting line: The impact of community and financial logics on new banking ventures. Academy of Management Journal, 55(6), 1381-1406.

Arnould, E. J. \& Thompson, C. J. (2005). Consumer culture theory (CCT): Twenty years of research. Journal of Consumer Research, 31(4), 868-882.

Ballantyne, D. \& Varey, R. J. (2008). The service-dominant logic and the future of marketing. Journal of the Academy of Marketing Science, 36(1), 11-14.

Barile, S. \& Polese, F. (2010a). Linking the viable system and many-to-many network approaches to service-dominant logic and service science. International Journal of Quality and Service Sciences, 2(1), 23-42.

Barile, S. \& Polese, F. (2010b). Smart service systems and viable service systems: Applying systems theory to service science. Service Science, 2(1-2), 21-40.

Barrett, M., Davidson, E., Prabhu, J., \& Vargo, S. L. (2015). Service innovation in the digital age: Key contributions and future directions. MIS Quarterly, 39(1), 135-154.

Battilana, J. \& Dorado, S. (2010). Building sustainable hybrid organizations: The case of commercial microfinance organizations. Academy of Management Journal, 53(6), 1419-1440.

Berger, P. L. \& Luckmann, T. (1967). The social construction of reality - A treatise in the sociology of knowledge, London: Penguin Group.

Binder, A. (2007). For love and money: Organizations' creative responses to multiple environmental logics. Theory and Society, 36(6), 547-571.

Chandler, J. D. \& Vargo, S. L. (2011). Contextualization and value-in-context: How context frames exchange. Marketing Theory, 11(1), 35-49.

Delbridge, R. \& Edwards, T. (2013). Inhabiting institutions: Critical realist refinements to understanding institutional complexity and change. Organization Studies, 34(7), 927-947.

DiMaggio, P. J. (1997). Culture and cognition. Annual Review of Sociology, 23(1), 263-287.

DiMaggio, P. J. \& Powell, W. W. (1983). The iron cage revisited: Institutional isomorphism and collective rationality in organizational fields. American Sociological Review, 48(2), 147-160.

DiMaggio, P. J. \& Powell, W. W. (1991). Introduction. P. DiMaggio, \& W. W. Powell (Eds.), The new institutionalism in organizational analysis, pp. 1-38. Chicago: University of Chicago Press.

Edvardsson, B., Tronvoll, B., \& Gruber, T. (2011). Expanding understanding of service exchange and value co-creation: A social construction approach. Journal of the Academy of Marketing Science, 39(2), 327-339.

Edvardsson, B., Kleinaltenkamp, M., Tronvoll, B., Mchugh, P., \& Windahl, C. (2014). Institutional logics matter when coordinating resource integration. Marketing Theory, 14(3), 291-309.

Ferreira, L. C., Caruana, R., \& Cohen, L. (2015). The use of institutional logics as cultural resources by social enterprises' employees. Academy of Management Proceedings, 1, 14685. 
EJMS

26,1

Friedland, R. \& Alford, R. (1991). Bringing society back. In P. J. DiMaggio \& W. W. Powell, (Eds.), The new institutionalism in organizational analysis, pp. 232-263. Chicago: University of Chicago Press.

Frow, P. \& Payne, A. F. (2011). A stakeholder perspective of the value proposition concept. European Journal of Marketing, 45(1/2), 223-240.

Geels, F. W. (2004). From sectoral systems of innovation to socio-technical systems. Research Policy, 33(6-7), 897-920.

Gonçalves, S. M., da Silva, R. V., \& Teixeira, N. (2019). Individual actors and embeddedness in businessto-business interactions. Industrial Marketing Management, 76, 181-191.

Granovetter, M. (1985). Economic action and social structure: The problem of embeddedness. American Journal of Sociology, 91(3), 481-510.

Greenwood, R., Oliver, C., Sahlin, K., \& Suddaby, R. (2008). Introduction. In R. Greenwood, C. Oliver, R. Suddaby, \& Sahlin, K. (Eds), The sage handbook of organizational institutionalism, pp. 1-46. London: SAGE Publications.

Guercini, S., La Rocca, A., Runfola, A., \& Snehota, I. (2014). Interaction behaviors in business relationships and heuristics: Issues for management and research agenda. Industrial Marketing Management, 43(6), 929-937.

Gummesson, E. \& Mele, C. (2010). Marketing as value co-creation through network interaction and resource integration. Journal of Business Market Management, 4(4), 181-198.

Hall, P. A. \& Taylor, R. C. (1996). Political science and the three new institutionalisms. Political Studies, 44(5), 936-957.

Hallett, T. (2010). The myth incarnate: Recoupling processes, turmoil, and inhabited institutions in an urban elementary school. American Sociological Review, 75(1), 52-74.

Hallett, T. \& Ventresca, M. J. (2006). Inhabited institutions: Social interactions and organizational forms in gouldner's patterns of industrial bureaucracy. Theory and Society, 35(2), 213-236.

Haveman, H. \& Rao, H. (1997). Structuring a theory of moral sentiments: Institutional and organizational coevolution in the early thrift industry. American Journal of Sociology, 102(6), 1606-1651.

Koskela-Huotari, K., Edvardsson, B., Jonas, J. M., Sörhammar, D., \& Witell, L. (2016). Innovation in service ecosystems - Breaking, making, and maintaining institutionalized rules of resource integration. Journal of Business Research, 69(8), 2964-2971.

Lusch, R. F. \& Webster, F. E. (2011). A stakeholder-unifying, cocreation philosophy for marketing. Journal of Macromarketing, 31(2), 129-134.

McColl-Keneddy, J. R. \& Cheung, L. (2019). Value cocreation: Conceptualizations, origins, and developments. S.L. Vargo, \& R.F. Lusch (Eds).The SAGE handbook of service-dominant logic, pp. 63-79. London: SAGE Publications.

March, J. G. (1991). How decisions happen in organizations. Human-Computer Interaction, 6(2), 95-117.

Merz, M. A., He, Y., \& Vargo, S. L. (2009). The evolving brand logic: A service-dominant logic perspective. Journal of the Academy of Marketing Science, 37(3), 328-344.

Meyer, J. W. \& Rowan, B. (1977). Institutionalized organizations: Formal structure as myth and ceremony. American Journal of Sociology, 83(2), 340.

Meyer, J. W. \& Rowan, B. (1983), The structure of educational organizations. In Meyer \& Scott (Eds), Organizational Environments: Ritual and Rationality, pp. 217-225. Beverly Hills: Sage Publications.

Mizruchi, M. S. and Fein, L. C. (1999), The social construction of organizational knowledge: A study of the uses of coercive, mimetic, and normative isomorphism. Administrative Science Quarterly, 44(4), 653-683. 
Moe, T. M. (1984). The new economics of organization. American Journal of Political Science, 28(4), 739-777.

North, D. C. (1990). Institutions, institutional change and economic performance, Cambridge University Press, Cambridge.

Potential of the institutional theory

Payne, A. F., Storbacka, K., \& Frow, P. (2008). Managing the co-creation of value. Journal of the Academy of Marketing Science, 36(1), 83-96.

Phillips, N. \& Malhotra, N. (2008). Taking social construction seriously: Extending the discursive approach in institutional theory. In Greenwood, R. Oliver, C. Suddaby, R. and Sahlin, \& K. (Eds.), The SAGE handbook of organizational institutionalism, SAGE Publications London. pp. $702-720$.

Powell, W. W. \& DiMaggio, P. J. (1991). The new institutionalism in organizational analysis, University of Chicago Press. Chicago.

Quader, M. S. \& Sohel, S. M. (2018). Strategic brand experience to differentiate B2B service offering: A case study analysis. The European Journal of Management Studies, 23(1), 49-82.

Rao, H., Monin, P., \& Durand, R. (2003). Institutional change in toque ville: Nouvelle cuisine as an identity movement in french gastronomy. American Journal of Sociology, 108(4), 795-843.

Scott, W. R. (1987). The adolescence of institutional theory. Administrative Science Quarterly, 32(4), 493-511.

Scott, W.R. (1995). Institutions and organizations. Thousand Oaks, CA: Sage Publications.

Scott, W. R. (2008). Approaching adulthood: The maturing of institutional theory. Theory and Society, 37(5), 427-442.

Scott, W. R. (2013). Institutions and organizations: Ideas, interests, and identities, 4th ed., SAGE Publications. Los Angeles:

Slimane, K. B., Chaney, D., Humphreys, A., \& Leca, B. (2019). Bringing institutional theory to marketing: Taking stock and future research directions. Journal of Business Research, 105, 389-394.

Swidler, A. (1986). Culture in action: Symbols and strategies. American Sociological Review, 51(2), 273-286.

Thornton, P. H. \& Ocasio, W. (1999). Institutional logics and the historical contingency of power in organizations: Executive succession in the higher education publishing industry, 1958-1990. American Journal of Sociology, 105(3), 801-843.

Thornton, P. H., Ocasio, W., \& Lounsbury, M. (2012). The institutional logics perspective: A new approach to culture. Structure, and process, Oxford: Oxford University Press.

Tilcsik, A. (2010). From ritual to reality: Demography, ideology, and decoupling in a post-communist government agency. Academy of Management Journal, 53(6), 1474-1498.

Townley, B. (1997). The institutional logic of performance appraisal. Organization Studies, 18(2), 261-285.

Vargo, S. L. \& Akaka, M. A. (2009). Service-dominant logic as a foundation for service science. Service Science, 1(1), 32-41.

Vargo, S. L., Koskela-Huotari, K., \& Vink, J. (2020). Service-Dominant logic: Foundations and applications. Bridges, E. \&Fowler, K. (Eds), The routledge handbook of service research insights andideas, Routledge. New York, NY, pp. 3-23.

Vargo, S. L. \& Lusch, R. F. (2004). Evolving to a new dominant logic for marketing. Journal of Marketing, 68(1), 1-17.

Vargo, S. L. \& Lusch, R. F. (2016). Institutions and axioms: An extension and update of servicedominant logic. Journal of the Academy of Marketing Science, 44(1), 5-23.

Vargo, S. L. \& Lusch, R. F. (2018). The SAGE handbook of service-dominant logic, London: SAGE Publications Limited. 
EJMS

26,1

16

Vargo, S. L., Wieland, H., \& Akaka, M. A. (2015). Innovation through institutionalization: A service ecosystems perspective. Industrial Marketing Management, 44, 63-72.

Vargo, S. L., Wieland, H., \& Akaka, M. A. (2016). Innovation in service ecosystems. Journal of Serviceology, 1(1), 1-5.

Wieland, H., Koskela-Huotari, K., \& Vargo, S. L. (2015). Extending actor participation in value creation: An institutional view. Journal of Strategic Marketing, 24(3-4), 210-226.

Wooten, M. \& Hoffman, A. (2008). Organizational fields: Past, present and future. In Greenwood, R. Oliver, C. Suddaby, R. \& Sahlin, K. (Eds), The SAGE handbook of organizational institutionalism. pp. 130-149. London: SAGE Publications.

Zucker, L. G. (1977). The role of institutionalization in cultural persistence. American Sociological Review, 42(5), 726-743.

\section{Corresponding author}

Sara Martins Gonçalves can be contacted at: agoncalves@iseg.ulisboa.pt.

For instructions on how to order reprints of this article, please visit our website: www.emeraldgrouppublishing.com/licensing/reprints.htm

Or contact us for further details: permissions@emeraldinsight.com 